\title{
THE IDEA OF PHILOSOPHICAL INITIATION AND PURIFICATION IN GORGIAS, PHAEDO, PHAEDRUS, AND SYMPHOSIUM OF PLATO
}

\begin{abstract}
The paper explores Plato's idea of philosophical initiation and purification in Gorgias (in the context of people's moral condition and ethical ideals they believe), and in some other dialogues of Plato (Phaedo, Phaedrus, and Symposium), in which Socrates refers to acts of initiation and purification, probably ones similar to the initiation into Greek mysteries. The essence and culmination of such initiation was marked by spiritual experience of the divinity of human soul. Similar subject matter may be found in some Socratic dialogues.
\end{abstract}

Keywords: Plato, initiations, philosophical initiation, philosophical purifications, Gorgias, Phaedo, Phaedrus, Symphosium, mysteries, Eleusinian mysteries, Orphic mysteries

1. Introduction. 2. The philosophical initiation and purification and their moral aspects in Plato's Gorgias. 3. The philosophical purification and initiation in the context of the idea of "melete thanatu" in Plato's Phaedo. 4. "The perfect mysteries" and "the madness of eros" in Plato's Phaedrus. 5. "The mysteries of eros" in Plato's Symposium. 6. Conclusion.

\section{INTRODUCTION}

This article focuses on an extremely compelling issue of "initiations," which appears in Plato's Gorgias in a seemingly unrelated context, that is in the context of a discussion on moral good and moral evil, raised by Socrates the moment he asked what is a lesser evil for a man: to hurt another person or to be hurt by others. As a result, not only two different ethical ideals and attitudes were confronted, but also two types of people - those who were initiated into the greatest mystery of human existence, and those who were not. Plato seems to suggest quite explicitly that only "the initiated ones" are capable 
of fully comprehending what is really good for man and how true nobleness and humaneness are expressed.

Gorgias is not the only Plato's dialogue in which the peculiar and mysterious motif of initiations is approached. It can also be found in other dialogues, i.a., in Phaedo, Phaedrus, and Symposium, although in different contexts, yet always such connected with the question of the mystery of the human soul and the meaning of human existence. It is an important motif, after all. It does fit into mysterial spirituality which surfaces in Plato's works, and which also shows other aspects of his philosophy.

\section{THE PHILOSOPHICAL INITIATION AND PURIFICATION AND THEIR MORAL ASPECTS IN PLATO'S GORGIAS}

In Gorgias Plato writes about the initiations in the context of his fundamental ethical principle of "Do Not Harm." This principle appears in many of Plato's dialogues but it is most thoroughly discussed in Gorgias. ${ }^{1}$ Plato's Socrates (which here seems to represent Plato himself) defends quite extensively his thesis proclaimed in Gorgias, nevertheless, as it will turn out, not effectively enough - or at least not as effectively as to win over the younger interlocutors, Callicles and Polos, who are both the supporters of "the law of the stronger" and a related thesis stating that pleasure is humans' main pursuit. At first, Socrates employs rational arguments, using logical means wellknown to him. However, one does not have to be fluent in logic to notice that his reasoning proves fallible from the very start. Socrates applies a thesis that a human being is inherently spiritual, hence his conviction that soul and all of its actions constitute the essence of humaneness and prioritize the values of human life. His logical defense

1 Plato, Gorgias, 474 B. Cf. ibid., 475 A - E; 479 C - D; 483 A - B; 489 A - B; 508 B - C; 509 C - D; 527 B. Cf. id., Republic, 345 A; Apology, 29 B; Crito, 47 E - 48 A. 
of the thesis is insufficient, though. ${ }^{2}$ The whole situation is perfectly evident, also to Socrates (who most probably represents Plato's own ideas). Perhaps that is why he resorts quite quickly to argumentation of a completely different nature, in this case - mythical, namely to an Orphic myth about an immortal, divine soul trapped in a mortal body. Pointing to an authority of some wise men, he compares body to grave and bodily life to death: "Who knows if life be not death and death life; ${ }^{4}$ and that we are very likely dead; I have heard a philosopher say that at this moment we are actually dead, and that the

2 Cf. Plato, Gorgias, 475 A - E.

3 In Gorgias Plato does not say whose idea it is, however, in Cratylus (400C) he speaks clearly of Orphics. many researchers have written about the religious and mystery aspects of the philosophy of Plato. Natorp in his well-known book, writes that Plato's philosophy is permeated with religion and is with her one piece: P. Natorp, Platos Ideenlehre, Hamburg 1961, 508, 509. Albert also thinks that the philosophy of Plato is a very religious, and even cult: K. Albert, Griechische Religion und Platonische Philosophie, Hamburg 1980, 68 and other. Albert even says that the philosophy of Plato is a continuation of Greek religion and reference is interrupted relationship with God (ibid, 121). Albert also accentuates the mystery, especially the Orphic qualities of Plato's philosophy. Similar interpretations of Plato are characteristic for others, especially German researchers, such as Willi and Fink: W. Willi, Die orphischen Misterien und der griechischen Geist, Eranos-Jahrbuch 11(1944), 61-105 (Willi is convinced that Plato attained the Orphic initiation and it determined his metaphysical thought); E. Fink, Metaphisik und Erziehung im Weltverständnis von Platon und Aristoteles, Frankfurt am Main 1970, 54-56. About orphic influence on Plato, see W. Jaeger, Teologia wczesnych filozofów greckich, tłum. J. Wocial, Kraków 2007, 149. The Orphic mystery are at the roots of the philosophy of Plato according to German Benedictine monk, Odo Casel in his De philosophorum Graecorum silentio mystico, Berlin 1976, 35-40. The Italian author of a classic work of history of ancient philosophy is convinced that without Orphism the thinking of philosophers such as Pythagoras, Heraclitus, Empedocles, or Plato cannot be explained: G. Reale, Historia filozofii starożytnej, t. I, tłum. E. Iwo Zieliński, Lublin 1993, 448. Similar characteristics in Greek philosophy were seen by A. Krokiewicz, Zarys filozofii greckiej. Od Talesa do Platona, Warszawa 1971, 7-69; Studia orfickie. Moralność Homera i etyka Hezjoda, Warszawa 2000, 52. Cf. K. Pawłowski, Misteria i filozofia. Misteryjne oblicze filozofii greckiej, Lublin 2007, 9-50.

4 Cf. Heraclitus B 62: "Immortals mortal, mortals immortal, living the death of those and having died the life of those." Transl. by Benjamin Jowett; text available online at http:// classics.mit.edu/Plato/gorgias.html. K. Mrówka, Heraklit, Warszawa 2004, 188. 
body (soma) is our tomb (sema), and that the part of the soul which is the seat of the desires is liable to be tossed about by words and blown up and down." 5

Referring to the authority of some wise men, as well as bringing up the popular Orphic myth, was supposed to provide support for the logical and rational argumentation, which apparently failed to persuade Socrates's young and impetuous interlocutors. When introducing the well-known Orphic myth about the immortal and divine soul, Plato's Socrates wishes to impress his opponents by suggesting that human nature can be understood differently than in the way it is perceived by Callicles, and, as a consequence, also human happiness can be understood differently. It is not necessarily just a never-ending struggle to satisfy desires which by nature cannot be satisfied. Socrates compares the soul of an unrestrained man (or, strictly speaking, this part of the soul that is responsible for desires) to a leaky cask, which is impossible to fill. ${ }^{6}$

Callicles, who believes that happiness means experiencing pleasure, guaranteed by satisfying various desires, is not particularly impressed by Socrates's story. ${ }^{7}$ Therefore, Socrates will soon reach for a myth more convincing to human imagination - for the eschatological myth.

When speaking about soul and her moral condition, Socrates points to some initiations: "[...] and that the part of the soul which is the seat of the desires is liable to be tossed about by words and blown up and down; and some ingenious person, probably a Sicilian or an Italian, playing with the word, invented a tale in which he called the soul - because of its believing and make-believe nature - a vessel,

5 Plato, Gorgias, 492 E - 493 A. Transl. by B. Jowett; text available online at http://classics. mit.edu/Plato/gorgias.html. Plato, Phaedo, 72 A; 72 E; 82 E; Plato, Phaedrus, 250 C. In Phaedrus there appears also the motif of soul imprisoned in its body like an oyster in its shell.

6 Plato, Gorgias, 493 B-C.

7 Ibid., 494 A - C. 
and the ignorant he called the uninitiated or leaky, and the place in the souls of the uninitiated in which the desires are seated, being the intemperate and incontinent part, he compared to a vessel full of holes, because it can never be satisfied. He is not of your way of thinking, Callicles, for he declares, that of all the souls in Hades, meaning the invisible world these uninitiated or leaky persons are the most miserable, and that they pour water into a vessel which is full of holes out of a colander which is similarly perforated. The colander, as my informer assures me, is the soul, and the soul which he compares to a colander is the soul of the ignorant, which is likewise full of holes, and therefore incontinent, owing to a bad memory and want of faith."

Plato is most evidently aware that the arguments he puts in his Socrates's mouth go beyond strictly logical reasoning, and that is why he makes him add the following words: "These notions are strange enough, but they show the principle which, if I can, I would fain prove to you; that you should change your mind, and, instead of the intemperate and insatiate life, choose that which is orderly and sufficient and has a due provision for daily needs. Do I make any impression on you, and are you coming over to the opinion that the orderly are happier than the intemperate? Or do I fail to persuade you, and, however many tales I rehearse to you, do you continue of the same opinion still?"'

We can all guess that Plato (Plato's Socrates) intends to reclaim Callicles morally. Plato does know that life cannot be changed in a blink of an eye just for the sake of one opinion or another. Life is an existential matter and it can only be altered by an existential experience, some internal sensation which will give a man intrinsic

8 Plato, Gorgias, 493 B. Por.: M. L. Gatti, Soma-Sema. L'ade e l'iniziato. „Giochi di parole” concernenti l'uomo, il filosofo e il retore-politico nella risposta di Socrate a Callicle nel "Giorgia" di Platone, Rivista di Filosofia Neo-Scolastica (2012)2/3, 261-288.

9 Ibid., 493 C. 
motivation and push him in the right direction. In other words, what is truly required here is an inner impulse in the form of a strong, existential internal sensation. Even the most precise logical argumentation, and such is almost out of reach when it comes to existential matters, will not do. There is something more required here. Plato sends his Socrates to look for this "something more" in mythology, mainly in the Orphic one, although clad in the gown of a slightly veiled philosophical parable. The motif of initiations mentioned by Socrates in Gorgias seems to suggest the same. Initiations are something that can be attained - not by adopting these or those views, but in the form of a more or less deep, yet always existentially experienced spiritual act.

The initiations referred to by Plato's Socrates in Gorgias (and not only there), are, as can be expected, similar to those attained by people initiated in mysteries, Orphic or Eleusinian, but also to philosophical mysteries reserved for the enthusiasts of wisdom and beauty. Allowedly, Plato himself was not initiated into Eleusinian mysteries, however, he most certainly knew the key idea behind them. Orphic spirituality must have been closer to his heart (although he does tend to criticize Orphic practices $\left.{ }^{10}\right)$, especially some of the Orphic ideas (the ideas of love, immortal soul, reincarnation, purifications and initiations themselves), which find their rightful place in Gorgias. Some of the motifs present in such dialogues as Phaedo, Phaedrus or Symposium are of clearly Orphic character. ${ }^{11}$ They appear in Gorgias as well, and they will be most powerful in the eschatological myth concluding this dialogue - the myth which serves as a final argument in Socrates's whole speech.

Coming back to the issue of initiations - Plato might have been familiar with mysterial initiations and related ordinations, and his humorous, yet telling remark addressed to Callicles, that he attained

10 V. Plato, Republic, 364 E - 365 A.

11 V. footnote 3. 
more advanced ordinations before the initial ones, is the best evidence of that. ${ }^{12}$ The initiations of such kind, greater and smaller ones (with the right order preserved), together with the consecutive degrees of mysterial initiation, were practiced for instance in Eleusis. ${ }^{13}$ At this point, it is worth mentioning that the initiations attained by initiates did not have much in common with getting at higher levels of knowledge or in priestly hierarchy. Nevertheless, initiation into some kind of more and more advanced secret knowledge and receiving higher and higher priestly positions (although it might have been the case in certain mysterial cults, for example during Isis and Osiris's mysteries in the times of Antonine dynasty in the Roman Empire) were never of the essence here. Such initiations did cast a light, also in a cognitive sense, on the greatest mystery of human existence and being, however, the acquisition of knowledge was not their most significant element. During mysterial initiations it was far more important to experience spiritually this great mystery, which was carried in the participants' hearts and felt deeply by them, the mystery of the divine character of one's soul (that is, the mystery of divinity settled in each of the partakers), and at the same time the mystery of divinity both hidden and manifesting itself in the world. Therefore, these initiations, which are the subject of our discussion, were not so much intellectual as they were spiritual. Presumably, they offered an authentic experience of sacrum, most probably mystical and in any case deeply spiritual, one which could open initiates to

12 Plato, Gorgias, 497 C.

13 Cf. U. Bianchi, The Greek Mysteries, Leiden 1976; W. Burkert, Ancient Mystery Cults, Harvard University Press, Cambridge 1987. K. Kerényi, Eleusi Archetypal Image of Mother and Daughter, Routledge \& K. Paul, London 1967; A. Krokiewicz, Studia orfickie, Warszawa 2000; E. Mylonas, Eleusis and the Eleusinian Mysteries, Princeton 1961; R. Reitzenstein, Die hellenistischen Mysterienreligionen nach ihren Grundgedanken und Wirkungen, Leipzig 1927; C. Schneider, Die antiken Mysterien in ihrer Einheit und Vielheit. Wesen und Wirkung der Einweihung, Hamburg 1979; W. von Uxkuli, Die eleusinischen Mysterien, Berlin 1927. 
the world of divine greatness, but also prepare them to the final, posthumous participation in the divine world.

The initiations were related to purifications of ethical nature. In the strict sense, the initiations themselves were the highest form of purifications - the mysterial experience of sacrum had the power to shape a man ethically, make him more sensitive to the highest values, and through that - purged and changed him morally.

As mentioned above, by the end of his narratives in Gorgias, which were to prove that moral nobleness is better than immorality, and getting hurt is better than hurting others, and also - that not harming anyone (neither by word nor by action) is the best thing a man can do for himself, ${ }^{14}$ Plato reaches for an argument of a different sort - for the eschatological myth. ${ }^{15}$ The myth tells stories of various people after their death. Its whole plot has been summarized at the very beginning: "that he who has lived all his life in justice and holiness shall go, when he is dead, to the Islands of the Blessed, and dwell there in perfect happiness out of the reach of evil; but that he who has lived unjustly and impiously shall go to the house of vengeance and punishment." ${ }^{16}$ The remaining part of Socrates's mythological story only complements the first sentence and does not provide any new pieces of information. However, by dint of its expression and ensuing poignancy, it does leave, or at least it can leave, a great impression on the listeners or readers, and this seems to be its role - to impress the audience, invoke internal sensations, like awe or fear of punishment in "hell" for injustice and harm done to other people, or hope for a happy life in those who did not hurt anyone. This is how Plato (through Socrates's mouth) explains in the first book of Republic the message

14 Plato, Gorgias, 522 C - D.

15 Ibid., 523 A - 526 D.

16 Ibid., 523 A - B. Similar in tone, although different as far as the tale itself is concerned, are the myths told by Plato in Phaedo and Republic, where they are also used to crown the whole argument. 
behind eschatological myths. ${ }^{17}$ The myth attempts at showing, even tangibly, the horror of moral evil, and convincing everyone that there is nothing worse than meanness and wickedness of the soul, yet, on the other hand, that there is nothing better and more noble than justice and human kindness. They are continued in the netherworld.

In Gorgias, Plato calls his myth a parable. ${ }^{18}$ In this way he suggests quite clearly, as one can think out, that in the substantive sense, it is not the tale which bears significance here but rather the message carried by it. ${ }^{19}$ The tale alone is only there to carry the message without the tale, the message would be lifeless or, at best, a crisp, dry formula that could not interest any readers. The tale makes the message clear and gets it across to the audience, which does not exhaust the role of the myth's tale. It serves also as some sort of catalyst of the sensations invoked by the message. Thus, the philosophical myth appears to function exactly in the way of the dramatic in their form and content mysterial myths. Another mark left by the mysterial heritage and the character of Plato's philosophy. In the mysteries, the myth or, strictly speaking, the drama developed on the basis of a myth about the gods worshipped in mysteries (like Dionisos-Zagreus in case of the Orphic mysteries, or Cora and Demeter in the Eleusinian mysteries), by means of its expressiveness, made impact on the initiates, sending them to elevated mystical states in which they experienced divinity. Most probably, this is what "great mysteries" in Eleusis consisted in. ${ }^{20}$ The Mystes was initiated into divinity, he experienced the mystery of the divine and supernatural character of his own soul - and the living presence of god and the supernatural

17 Plato, Republic, 330 D - 331 A.

18 Plato, Gorgias, 523 A. Cf.: Id., Phaedo, 114 D.

19 Cf. K. Albert, op. cit., 27-38; 96-108; Id., Vom Kult zum Logos, Hamburg 1982, pp. 1-15; O. Casel, op. cit., 92-93; P. Friedlander, Platon, vol. I, Berlin 1964, pp. 182-222; K. Hildebrant, Platon, Logos und Mythos, Berlin 1959; J. Pieper, Über platonische Mythen, München 1965; E. Wolicka, Mimetyka i mitologia Platona, Lublin 1994.

20 Ibid. footnote 15. 
in the world. The myth told by Plato does not lead to such intensive feelings, but it can encourage reflection and even the simple sensation of fear of punishment and hope for a prize, as Plato admits in Republic. ${ }^{21}$ It would be far better, according to his suggestion from Gorgias, if our lives were not guided by the fear of punishment for wickedness and meanness, or by the hope for a prize for honesty and righteousness - but simply navigated by honesty and righteousness themselves. ${ }^{22}$ However, the majority of people need some motivation to live in honesty - at best it could be religious motivation of the kind offered by Plato's Socrates in Gorgias.

The message behind the eschatological myth in Gorgias is rather clear. The myth, in its deepest form, shows that nobleness and righteousness towards other people are values in themselves, absolute and immortal. At the same time, it is something on which the most noble and elevated human values can grow, and in which men fulfill themselves in the living and existential sense, while completing the act of creation - the creation of themselves; also, people open a secret gate through which they can see a different world - the world of both supernatural and elating Truth, Beauty, and Goodness. And this is how they discover the secret of their own happiness.

\section{THE PHILOSOPHICAL PURIFICATION AND INITIATION IN THE CONTEXT OF THE IDEA OF “MELETE THANATU” IN PLATO'S PHAEDO}

Plato's philosophy preserved the idea of purification, whose function was regarded in the same manner as in mysteries, although the formula underwent deep change - now its aim was the intentional quest for Truth and experience thereof, as well as the love of Beauty and Goodness. It lost, if we may say so, the religious frame, but it still concerns the authentic experience of absolute, sacrum, or, to be more

21 Plato, Republic, 330 D - 331 A.

22 Plato, Gorgias, 527 B. 
precise: the supernatural Goodness, the divine source of every other goodness, including the moral goodness, which comes to existence through human actions. The focus of both philosophical and mysterial purifications is the mystical (or simply spiritual) experience of absolute, divine and supernatural values. Obviously, such experiences require a great moral and spiritual sensitivity (as a prerequisite), but they also help to increase this sensitivity. Plato mentioned this on many occasions and in many dialogues. ${ }^{23}$ Philosophical purifications do not serve to fulfil the egoistical desire for eternal happiness, which often is a motif for conducting mysterial initiations; their only purpose is to enable the initiated to learn the Truth, attainable only for pure spirits devoid of all sensual aspects. At the same time, Truth is philosopher's constant companion, as suggested by Plato in the Phaedo. ${ }^{24} \mathrm{He}$ associates philosophical purification with detaching the soul of everything related to carnality and worldly issues, which is a state that may be achieved in full only after one's death. ${ }^{25}$ Therefore, philosophy is for Socrates a means to prepare for death, a form of training, practicing dying. ${ }^{26}$

In this same Phaedo Socrates mentions some sort of secret initiation which feels like being possessed of by gods, hence, a form of experiencing divinity, the sacrum: "And I conceive that the founders of the mysteries had a real meaning and were not mere triflers when they intimated in a figure long ago that he who passes unsanctified and uninitiated into the world below will live in a slough, but that he who arrives there after initiation and purification will dwell with the gods. For "many," as they say in the mysteries, "are the thyrsus

23 Cf. Plato, Republic, 485 B - 486 D; 490 C-D; 500 B-D; Letters, VII 343 E - 344 B; Theaetetus, $173 \mathrm{D}-175 \mathrm{C}$, op. cit., 75-78.

24 Plato, Phaedo, $69 \mathrm{~B}$.

25 Ibid., 67 C-D.

26 Ibid., 67 E. Cf.; Ibid., 64 A, B; 80 E. 
bearers, but few are the mystics"- meaning, as I interpret the words, the true philosophers." ${ }^{27}$

In Phaedo, just like in Gorgias, initiation (philosophical initiation in general) and purification are connected to attaining some kind of divinity - that is; divine moral perfection and wisdom, or at least other values considered to be divine and therefore, to constitute an element of sacrum enshrining the world and the immortal soul of man. Thus, philosophy is found to similar to over mysteries - it initiates its adepts (if only they have achieved a required degree of moral and spiritual sensitivity) and brings them into the world of absolute values, Beauty, Goodness, and Truth. Initiations are always coupled with experiencing divinity and the philosophical ones constitute no exception to the rule - the experience of Beauty, Goodness, and Truth, is, after all, nothing else than experiencing divinity in the form in which it presents itself most fully. Beauty, Goodness and Truth, once they begin manifesting themselves in a most mysterious manner in the philosopher's soul, remain there forever, as a peculiar sign and the call of the divine supernatural essence.

\section{4. "THE PERFECT MYSTERIES" AND "THE MADNESS OF EROS" IN PLATO'S PHAEDRUS}

The idea of initiation comes to play in one of the undoubtedly most interesting works of Plato: the Phaedrus - and it is introduced there in a very special way, which is mysterial and mystical at the same time. Further discussion of these topics in the Phaedrus beyond the scope of this work. Enough to say that Plato (Plato's Socrates) in Phaedrus is straightforward in associating initiations with what he calls the madness of Eros, ${ }^{28}$ by which he means the madness of

27 Ibid., 69 C-D.

28 Ibid., Plato, Phaedrus, 249 D. 
love, sent to us, like all kinds of madness, by god. ${ }^{29} \mathrm{It}$ is one of the four noble kinds of madness coming from the gods ${ }^{30}$ and the most precious of them; it is the god's greatest gift to mankind. ${ }^{31}$ In saying so, Plato implies that his concept of love as madness, god-induced inspiration (and, analogically, the concept of poetic, prophetic and mystic inspirations as beings of similar nature) is irrational in the sense that it cannot be grounded in rational premises and justified by means of logic alone. For this reason, claims Plato, no wiseacre could accept his views - and, if we may add, nor could he accept the idea of god's active presence in the world. Nonetheless, a true philosopher, someone who has himself communed with the divine wisdom and, hence, is also somehow touched by the madness, would recognize the truth of them. ${ }^{32}$

The context in which the motif of philosophical initiation is presented in Phaedrus is the famous picture of gods in winged chariots, dashing through space lead by Zeus. The chariots are followed by a swarm of other spirits, good and bad, who are positioned in such a way, that every one of them belongs to the retinue of the appropriate god. Among the spirits, human souls are to be found. Everyone, including Zeus, is heading for the top of heaven, from where they slid to the other side, and on their way they can see the realm, that - in Socrates's words - cannot be described by words, the realm of Truth and absolute values.

And this is the moment in which Plato evokes the image of "the perfect mysteries," which can be achieved by those, who live by the memory of the blessed, joyful sights that his soul has watched during its wanderings with gods. These initiations cause man to forget all human matters, to live only in the realm of what is divine and, at

29 Ibid., $244 \mathrm{~A}$.

30 Ibid., 244 A - 245 B; 265 B-C.

31 Ibid., 245 B - C; see also Ibid., 249 E.

32 Ibid., $245 \mathrm{C}$. 
the same time, to taste some of the forgotten happiness of the soul. This is why the vulgar would deem him mad, and rebuke him; they do not see that he is inspired by god: "And therefore the mind of the philosopher alone has wings; and this is just, for he is always, according to the measure of his abilities, clinging in recollection to those things in which God abides, and in beholding which $\mathrm{He}$ is what $\mathrm{He}$ is. And he who employs aright these memories is ever being initiated into perfect mysteries and alone becomes truly perfect. But, as he forgets earthly interests and is rapt in the divine, the vulgar deem him mad, and rebuke him; they do not see that he is inspired." 33

The phrase "he is inspired" means that "he is inspired by god," or, even better "he is touched by god's madness." It turns out, therefore, that all that which is the fate of a philosopher, is in fact the outcome of the madness of Eros, the most noble of the four kinds of madness (endowed on people by the gods). Socrates makes it quite clear: "Thus far I have been speaking of the fourth and last kind of madness, which is imputed to him who, when he sees the beauty of earth, is transported with the recollection of the true beauty; he would like to fly away, but he cannot; he is like a bird fluttering and looking upward and careless of the world below; and he is therefore thought to be mad. And I have shown this of all inspirations to be the noblest and highest and the offspring of the highest to him who has or shares in it, and that he who loves the beautiful is called a lover because he partakes of it." ${ }^{34}$

The constant spiritual contact with the realm of truth is precisely what Socrates meant by perfect initiation. He connects the experience of initiation to some kind of perception of the absolute, divine values. For this reason, someone who has been initiated is called someone 
inspired by god. A similar idea is put forth in Phaedo, where Socrates speaks of philosophers who love wisdom with their whole souls. ${ }^{35}$

The subject of initiation as a form of perceiving and absorbing the realm of the truth and the absolute values is also mentioned twice in the Phaedrus. This time, he describes the state of a soul (a philosopher's soul) awaiting its first incarnation, when it is still among the gods, admiring the realm of the absolute and supernatural values. Now this is called the initiation opening the secret gates of happiness - the highest happiness - and it is associated with the contemplation of divine secrets: "There was a time when with the rest of the happy band they saw beauty shining in brightness-we philosophers following in the train of Zeus, others in company with other gods; and then we beheld the beatific vision and were initiated into a mystery which may be truly called most blessed, celebrated by us in our state of innocence, before we had any experience of evils to come, when we were admitted to the sight of apparitions innocent and simple and calm and happy, which we beheld shining impure light, pure ourselves and not yet enshrined in that living tomb which we carry about, now that we are imprisoned in the body, like an oyster in his shell." ${ }^{\prime 36}$

This is where Plato reveals in the fullest manner the essence of the initiation of which so much has been spoken. As we can see, they are the contemplation of the mysteries of the realm of the truth and the supernatural absolute values - such mysteries are blessed, which means that they bring happiness to those, who examine them and who feed on them (Socrates has already explained that the sight or the remembrance of this realm is the nourishment of the soul). We should not overlook the connection between the happiness and the aforementioned contemplation. For this is the happiness sought after

35 Plato, Phaedo, 69 C-D.

36 Plato, Phaedrus, 250 B-C. Transl. by Benjamin Jowett, text available at http://classics. mit.edu/Plato/phaedrus.html. 
and desired by people who are usually unaware, that it is so close, that it lies within the reach of their soul, it would suffice to make an effort to study its depths, following the call of the natural human sensitivity to Truth, Beauty, and Goodness.

We have to bring attention to another aspect of the mysterious initiations of philosophy. Socrates emphasizes strongly the question of the moral and spiritual state of the souls that are to become initiated. He stresses that they have to be pure and undefiled by evil, induced by the body. Moral and spiritual purity are something people, and particularly philosophers will always yearn for in their heart of hearts. This secret yearning will be drive their incessant quest for the truth, moral beauty and spiritual goodness. On the other hand, this yearning, although perhaps somewhat puzzling, constitutes a kernel of a specific philosophical sensitivity and hence, it is the necessary prerequisite to practice philosophy and lead a philosophical life in general. Without it, it would seem, philosophy is altogether impossible. ${ }^{37}$

At the end of the quote, Socrates fortifies the image characteristic of a philosopher of his standing - that his soul is imprisoned in his body. He also made it clear once more, that the soul itself is divine, again with help of an Orphic motif (the oyster in the shell). Picturing the soul as a pearl closed in a shell enabled Socrates to present philosopher's existential condition, his longing for the realm of the Truth, Beauty and Goodness, and especially the relation between the soul and the body, which are joined together in a one being, called the mortal man. ${ }^{38}$

37 Cf. Plato, Letters, VII, 343 E - 344 B; 340 C. Plato's reflections on the intellectual, spiritual, and moral requirements for the adepts of philosophy are to be found in many dialogues (the most important seem to be the ones in Plato's Republic, Phaedo, Phaedrus, and Theaetetus).

38 Cf. Plato, Phaedrus, 246 C. 


\section{5. “THE MYSTERIES OF EROS” IN PLATO'S SYMPOSIUM}

Such are the spiritual experiences described by Socrates with a distinctly mystical air in a dialogue that we cannot fail to mention at this stage, namely, in the Symposium. Socrates recalls his talk with Diotima, a mysterious woman from Mantinea, probably a prophet who initiated Socrates into the mysteries of Eros. ${ }^{39}$ Diotima told him, among other things, about a secret and wonderful experience, in which a lover of beauty (a philosopher, that is) could sense the absolute Beauty. It resembled an ecstatic, mystic and amorous sensation which satisfied all the needs and yearnings of his love: "when he comes toward the end will suddenly perceive a nature of wondrous beauty (and this, Socrates, is the final cause of all our former toils) - a nature which in the first place is everlasting, not growing and decaying, or waxing and waning." ${ }^{.40}$ It is worth noticing that the experience depicted above by Diotima has its foundation in a mysterious love longing for the Beauty (which is at the same time perfectly natural, like a natural tension in the soul, leading it in the direction of the realm of the supernatural). Beauty is equally mysterious as the love itself and it is absolute (because a philosopher always has to seek what is absolute). Initially, the love is directed at various kinds of earthly beauty, however it is in the absolute Beauty that it finds it fulfilment, because the absolute Beauty is the source of every other beauty (including the moral one). Thus, there is nothing surprising in the fact that a philosopher can only find satisfaction and happiness in the contemplation of this absolute and divine Beauty.

39 Plato, Symposium, 209 E - 211 B.

40 Ibid. 


\section{CONCLUSION}

Let us come back to Plato's Phaedrus, presumably the most "mysterial" and "enigmatic" of all dialogues of this philosopher. Undoubtedly, Phaedrus is not only one of Plato's most beautiful dialogues, but, above all, it is one of the most inspiring ones. Reale speaks of it as "un dialogo cruciale." ${ }^{\text {"11 }}$ Indeed, this dialogue may have the crucial influence on the understanding and practicing of philosophy. This time we shall reach for the final part of the dialogue, in which Plato (Plato's Socrates) discusses the popular issue of the value of writing itself and writing in philosophy. As it turns out, writing is just a play in comparison with living word. Only living word has the power to rouse a philosopher's soul, ${ }^{42}$ while writing - does not. Writing these are those famous "gardens of Adonis," the ones planted by farmers once in a blue moon, partly in order to check the quality of grains, partly for pure amusement. ${ }^{43}$ Obviously, Plato, although writes a lot himself, will be in favour of living word. And why is that? For philosophy can be entrusted only to living language, yet not any language, but to that one which - filled with genuine light - is able to strike the most secret chords of a philosopher's soul and open her to the world of supernatural values, to what is truly Beautiful, Just, and Good..$^{44}$ If we are to enter the spirit of Plato's words (naturally, with reference to the whole Phaedrus, and in the context of the vision of souls as chariots presented therein), it is not hard to understand which language and which light are of interest here. It is about what happens within soul. Yet in a soul which in herself belongs to the supernatural reality, nothing can be started without her characteristic relation to the supernatural, and such relations are always created

41 K. Gaiser, L'oro della sapienza. Sulla preghiera del filosofo a conclusione del "Fedro" di Platone, Introduzione e traduzione di Giovanni Reale, Vita e Pensiero, Milano 1996, 14.

42 Plato, Phaedrus, 274 B - 278 E.

43 Ibid., 276 B.

44 Ibid., 278 A-B. 
beyond rationality, therefore without words. The soul's proper relation with the supernatural is the spiritual (thus inherently existential and superintellectual) experience of the mystery of the supernatural. An "external" (uttered) word serves as a means of awaking the spiritual dispositions of soul, among which there are spiritual sensitivity and moral sensitivity. What is of the highest significance here happens in the very soul, in the realm of existential spiritual experiences, which transcend human rationality (certainly, not in a sense that they are beyond the control of mind - the mind needs to be in control of any acts and experiences of a man in order to prevent him from falling into mental irrationality, or, in other words, not to let him succumb to superstitions and prejudice). The soul's proper disposition and power, which opens her to the world of supernatural greatness, is her natural (since constituting the soul's natural endowment) spiritual sensitivity.

Human spiritual sensitivity, manifesting itself as a strange and mysterious longing for something as strange and mysterious as the longing itself, can initiate a man into the world of the deepest mysteries (existential mysteries), including the most profound of all the mysteries of human nature and human existence, and the mystery of human love inseparable from it, all of which cannot be solved even in the most logically proficient deductions (whether written or spoken), that is by depending solely on mind and logic characteristic of it. Human mind is capable of comprehending and solving only strictly rational matters. Existential issues seem too overwhelming to it. At this point a different sort of dispositions and a different sort of sensitivities shall be triggered off (different from those closely connected with human rationality and sensuality), namely spiritual and moral sensitivity. They are also the natural endowment of human nature, however, they might remain dormant and obscured by the ideological "noise" of civilization and culture. A word (also a written one - let Plato's own words serve as the best proof of that) can set in motion the process of awaking this sensitivity. Such is the purpose of Plato's philosophy, and, in particular, of what is hereby called "the Socratic 
method," that is "the maieutic (midwife) method." Nevertheless, "the truth" touching upon the deepest mysteries of human nature and human existence can be born in soul only, as has been suggested, in a living, existential relation with the supernatural. No word and no language, even most scholarly, shall not be capable of doing that. Only love which reaches to the supernatural has such power - and this is the most important conclusion of the present study. Such love (as it has its source in the realm of the supernatural) is able to awaken what is most noble and at the same time most divine (thus supernatural) in a man, and, as a result, lead him to divinity (the supernatural). This is what initiation, as we call it, consists in.

\section{REFERENCES}

Ancient sources

Platonis Opera, ed. J. Burnet, Oxford 1903.

Modern works

Albert K., Griechische Religion und Platonische Philosophie, Hamburg 1980.

Albert K., Vom Kult zum Logos, Hamburg 1982.

Bianchi U., The Greek Mysteries, Leiden 1976.

Burkert W., Ancient Mystery Cults, Cambridge: Harvard University Press, 1987.

Casel O., De philosophorum Graecorum silentio mystico, Berlin 1976.

Fink E., Metaphisik und Erziehung im Weltverständnis von Platon und Aristoteles, Frankfurt am Main 1970.

Friedlander P., Platon, vol. I, Berlin 1964.

Gatti M. L., Soma-Sema. L'ade e l'iniziato. „Giochi di parole” concernenti l'uomo, il filosofo e il retore-politico nella risposta di Socrate a Callicle nel "Giorgia" di Platone, Rivista di Filosofia Neo-Scolastica (2012)2/3, 261-288.

Gaiser K., L'oro della sapienza. Sulla preghiera del filosofo a conclusione del "Fedro" di Platone. Introduzione e traduzione di Giovanni Reale, Vita e Pensiero, Milano 1996.

Hildebrant K., Platon, Logos und Mythos, Berlin 1959.

Jaeger W., Teologia wczesnych filozofów greckich, transl. J. Wocial, Kraków 2007 (Die Theologie der frühen griechischen Denker, Stuttgart 1953). 
Kerényi K., Eleusis Archetypal Image of Mother and Daugter, Routledge \& K. Paul, London 1967.

Krokiewicz A., Zarys filozofii greckiej. Od Talesa do Platona, Warszawa 1971.

Krokiewicz A., Studia orfickie. Moralność Homera i etyka Hezjoda, Warszawa 2000.

Mrówka K., Heraklit, Warszawa 2004.

Mylonas E., Eleusis and the Eleusinian Mysteries, Princeton 1961.

Natorp P., Platos Ideenlebre, Hamburg 1961.

Pawłowski K., Misteria i filozofia. Misteryjne oblicze filozofii greckiej, Lublin 2007. Pieper J., Über platonische Mythen, München 1965.

Reale G., Historia filozofii starożytnej, vol. I, transl. E. Iwo Zieliński, Lublin 1993 (Storia della filosofia antica, Milano 1989).

Reitzenstein R., Die hellenistischen Mysterienreligionen nach ibren Grundgedanken und Wirkungen, Leipzig 1927.

Schneider C., Die antiken Mysterien in ibrer Einheit und Vielheit. Wesen und Wirkung der Einweihung, Hamburg 1979.

Uxkuli W. von, Die eleusinischen Mysterien, Berlin 1927.

Willi W., Die orphischen Misterien und der griechischen Geist, Eranos-Jahrbuch 11(1944), 61-105.

Wolicka E., Mimetyka i mitologia Platona, Lublin 1994.

KAZIMIERZ PAWŁOWSKI

k.pawlowski@uksw.edu.pl

Cardinal Stefan Wyszynski University in Warsaw, Institute of Classical Philology and Cultural Studies

Dewajtis 5, 01-815 Warsaw, Poland

DOI 10.21697/spch.2016.52.1.04 